\title{
“Anaforun İçinde” bir kadın: Yevgeniya Ginzburg
}

\section{Reyhan ÇELIKK}

\begin{abstract}
APA: Çelik, R. (2019). "Anaforun İçinde” bir kadın: Yevgeniya Ginzburg. RumeliDE Dil ve Edebiyat Araştırmaları Dergisi, (17), 526-535. DOI: 10.29000/rumelide.657933

Yaşamak, yaşamak istiyorum çılgınca

Ölümsüz olan her şey gibi.

Kimliksiz, salt bir insan olmak,

Sönen düşleri yeniden gerçeğe dönüştürmek.
\end{abstract}

A. Blok

\section{$\ddot{0} \mathbf{z}$}

Rusya tarihinde 20. yüzyıl, içinde pek çok tarihi ve toplumsal olayları barındıran karmaşık bir yüzyıldır. Birinci ve İkinci Dünya savaşları, Bolşevik Devrimi ve iç savaş bunlardan bazılarıdır. 1930’lu yıllar da 20. yüzyll Rus siyasi tarihinin en önemli kırılma noktalarından biridir. Nitekim partinin önemli isimlerinde Sergey Kirov'un öldürülmesinin ardından parti içinde pek çok tutuklanma ve ardından gelen idam cezaları dikkat çeker. Yevgeniya Solomonovna Ginzburg da 1937 yılında casusluk suçlaması ile tutuklanır. Yaklaşı üç yılını hapishanelerde, on beş yılını da Gulag kamplarında mahkûm olarak geçirir. Ginzburg 1937- 1955 yılları arasındaki bu zorlu yıllarda yaşadığı ve çevresinde gözlemlediği pek çok olayı “Anafora Doğru” ( крутой маршрут 1 ) ve "Anaforun İçinde” (крутой маршрут 2) adlı otobiyografik romanlarında anlatır. Kitapları Rusya’da ancak ölümünden on yıl sonra, 1988 yılında yayınlanabilir. Ginzburg iki ciltlik eserinde, bir komünist parti çalışanı olarak, yaşadıkları karşısında hissettiği şaşkınlığı ve merakı dile getirdiğini belirtir. Bu çalışmanın amacı, 3o'lu yaşlarında tutuklanarak casuslukla suçlanan ve yaşamının on beş yılını ıslah ve zorunlu çalışma kamplarında geçiren Y. Ginzburg'un “Anafora Doğru” ve “Anaforun İçinde” eserlerinde kamp yaşamı ile ilgili anlattıklarını değerlendirmektir. Bu değerlendirmede tarihsel yöntem kullanılacaktır. $\mathrm{Bu}$ nedenle Sovyet döneminde yaşanan politik gelişmelerin islah ve zorunlu çalışma kamplarına etkisini yazılı kaynaklarla da destekleyip sonuca ulaşmak hedeflenmektedir.

Anahtar klimeler: Gulag, büyük temizlik, Yevgeniya Ginzburg, çalışma kampları.

\section{A woman "Within the Whirlwind": Evgenia Ginzburg}

\begin{abstract}
In Russian history, the 2oth century is a complex period with many historical and social events such as World War I, World War II, Bolshevik Revolution and Civil War. The 1930's is also one of the most important breaking points of the Russian political history in the twentieth century. Thus, after the murder of S. Kirov, one of the prominent names of the party, many arrests within the party and the subsequent death sentences take place. Yevgenia Ginzburg is arrested with the accusation of spying in Ginzburg in 1937. She spends about three years in prison and 15 years in captivation in Gulag camps. Ginzburg describes many of the events she has experienced and observed around in these difficult years (1937 - 1955) in her autobiographical novels titled "Journey into the Whirlwind" and

1 Doç. Dr., Akdeniz Üniversitesi, Edebiyat Fakültesi, Rus Dili ve Edebiyatı Bölümü (Antalya, Türkiye), reyhan3104@gmail.com, ORCID ID: 00oo-0oo2-9743-3720 [Makale kayıt tarihi: 18.11.2019-kabul tarihi: 20.12.2019; DOI: $10.29000 /$ rumelide.657933]




\begin{abstract}
"Within the Whirlwind". Her books are able to be published in Russia in 1988, only ten years after her death. In her two-volume work, Ginzburg states that, as a communist party worker, he depicts his maze and curiosity about his experiences. The aim of this study is to evaluate the narration about the camp life in the works "Journey into the Whirlwind" and "Within the Whirlwind" of Ginzburg, who was arrested and accused of spying in her 30's and spent 15 years of her life in correction camps and Gulags. In this assessment, historical method will be used. Therefore it is aimed to support the effect of political developments in Soviet era on the correction camps and gulags with written sources.
\end{abstract}

Keywords: Gulag, great purge, Yevgenia Ginzburg, labor camps.

\title{
Giriş
}

Sovyet tarihinin gerçeklerinden biri olan hapishaneler, sürgünler ve kamp yaşamı milyonlarca kişinin yaşamak zorunda kaldığı bir durumdur. Aleksandr Soljenitsın, Varlam Şalamov, İbrahim Salahov vb. pek çok yazar, edebi sanatlarında kamp gerçekliğini yaşamış ve bunları dile getirmişlerdir. Her biri kendi bakış açısı ve yaşanmışlıkları ile ıslah ve çalışma kamplarını dile getirmiş olsa da bu anlatılanların ortak yanı çekilen acılardır. Ekmek kırıntısına muhtaç olmanın verdiği acı, kamplardaki insanların birer birer ve yavaş yavaş ölmesi, açlığa ve soğuğa karşı koyma mücadelesi ve bütün bunlara rağmen özgürce yaşama umudu. Bunların hepsi anlatılanların ortak noktalarıdır.

Kendi kanunlarını, değerlerini, kendine özgü küfürlerini, kendi edebiyatını, kendi canilerini, kendi kahramanlarını oluşturan ve sadece mahkûmların değil gardiyanların bile üzerinde kendi kalıcı izlerini bırakan GULAG² (Главное управление исправительно-трудовых лагерей) kampları tutuklama, soruşturma, hayvan vagonlarında taşınma, zorla çalıştırma, ailelerin parçalanması, sürgünde geçirilen yıllar, erken ve gereksiz ölümlerle anılmıştır ( Applebaum, 2008, s.16).

GULAG kampları Stalin döneminde milyonlarca Sovyet insanının ölmesine yol açan kamp sistemi olarak bilinmesine karşılık kökleri Çarlık Rusya'sına, on yedinci yüzyıldan yirminci yüzyıl başına kadar Sibirya'da işletilen zorunlu çalışma taburlarına dayanır. 1918 yllında ise Lenin'in "güvenilmez unsurlar" ın kentlerin dişındaki toplama kamplarına kapatılmasını emretmesi ile potansiyel düşman olarak nitelendirilen kişiler bu kamplara gönderilirler. 1921'de çoğunluğu halk düşmanlarını rehabilite etmek için kurulmuş kırk üç eyalette seksen dört kamp bulunuyordu. 1929'dan itibaren kamplar yeni bir önem kazandılar. O yıl Stalin, Sovyetler Birliği'nin hem sanayileşmesini hızlandırmak hem de neredeyse hiç kimsenin yaşamadığı ücra kuzeyindeki doğal kaynaklarını yeraltından çıkarmak için zorunlu çalışmayı uygulamaya karar verdi (Applebaum, 2008, s.16). Dolayısıyla kampların kurumasında rejim karşıtlarının cezalandırılması amaçlanmış gibi görünse de "cezalıların bedava işgücünü sistemli bir şekilde kullanarak, Sovyet ekonomisinin gelişmesine katkı sağlama" ( Khairmukhanmedov, 2007, s.155 ) amacı güdüldüğü görülmektedir. Kamp sisteminin idaresi 19221934 yılları arasında GPU ( Государственное политическое управление ) olarak, 1934 sonrasinda içişleri komiserliğinde NKVD ( Народный комиссариат внутренних дел ) sonrasında MGB ( Министерство государственной безопасности ) 1954 sonrasinda KGB (Комитет государственной безопасности ) olarak bilinen siyasi polis, zorunlu çalışma kamplarının muhafızlığını ve idaresini üstlendi ( Riasanovski, 2011, s. 545).

Kurulan kamplar ağırlıklı olarak çeşitli maden kaynaklarının bulunduğu, merkezden uzak Sibirya topraklarını kapsar. Rusya coğrafyasının en soğuk bölgelerinden birini oluşturan Sibirya, tarihsel bir

GULAG: Islah-Çalışma Kampları ve Kolonileri Genel İdaresi 
gerçekliktir. Bu gerçeklik yazarların ya da şairlerin edebi eserlerinde tema ya da motif olarak karşımıza çıkar. Prof. Dr. Emine İnanır da "Rus Edebiyatında Bir Topos Olarak Sibirya" adlı çalışmasında bunu ifade eder:

Sibirya birbiriyle iç içe olan iki anlam içerir: biri, topografya olanı, içerisinde derya gibi zenginlikler barındıran bir coğrafya, diğeri ise siyasal, toplumsal, kültürel bir alan, binlerce sürgünün ve hükümlünün kaderini, hayallerini içinde taşıyan, birçok yazarın eserlerinde yer verdiği "imajlar, motifler halinde" bir topos (İnanır, 2018, s.65).

Sovyet kamp sisteminin tarihini tüm yönleri ile inceleyen Anne Applebaum, Sibirya'daki ilk esir kampının Solovki olduğunu ve bu kampın hafizalarda yer ettiğini belirtir: "Araştırmacılar o zamana kadar birçok ceza evinin ve kampın olduğunu belirtmiş olsalar da Solovki, şüphesiz yalnızca eski mahkûmlarm değil, aynı zamanda Sovyet organlarında görevli olanların amılarnda da önemli bir yer teşkil etmiştir" (Applebaum, 2008, s.53).

Sovyet ekonomisinin gelişimi için ihtiyaç duyulan insan gücünü karşllamak amacı ile kurulan kampların sayısının zamanla çoğaldığı görülür. Zira Sovyetler birliğinin varlığı boyunca 476 önemli kamp tesisi oluşturulduğu bilinmektedir. Ayrıca bu kamplardan, 1929'dan 1953’e, Stalin'in ölümünden sonra ortadan kaldırılmasına kadar yaklaşı 18 milyon Sovyet insanının geçtiği sanılmaktadır (Bkz. Applebaum, 2008, s.16-17).

Bu tarihi süreç içerisinde 1936-1938 yılları ise oldukça önemlidir. Bu yıllar, Büyük Temizlik (Büyük Tasfiye; Büyük Terör) (Bol'şaya çistka) hareketinin gerçekleştirildiği ylllar olarak Sovyet tarihinde yerini alır. Yaşanan bu olayların çıkış noktası olarak Leningrad'da üst düzey parti lideri olan Sergey Kirov'un öldürülmesi gösterilir. Yazar İlya Erenburg 1934 yılı Kasım ayı sonunda Stalin’le görüşmek için Moskova'ya geldiğinde, bu haberi ilk olarak Buharin'den "Felaket! Kirov'u öldürmüşler." sözleri ile duyar. Bu haber yeni bir dönemin, yeni bir anlayışın başlangıcı olacaktır. "Hepimiz bu haberle üzülmüş̧ük. Kirov’u seviyorduk. Acımıza bir de endişe eklenmişti: Kim? Niçin? Sonrası ne olacak?...Hiç şüphe yok ki hiçbirimiz, yeni bir devrin başladiğım sezmemiştik. Ama hepimiz suspus olmuş, dikkat kesilmiştik” (Erenburg, 1968, s.206).

Nitekim Erenburg'un belirttiği “yeni bir devir” Kirov’un öldürülmesinin ardından ard arda gelen parti içi tutuklamalar ve idamlarla başlar. Ülkenin her yerinde farklı konumdaki insanlar bir gece ansızın kapılarının çalınmasından tutuklanmaktan korkarlar. Bu yıllarda siyasi suçlu olarak yakalanmış insan sayısının yaklaşık 3,5 milyon, "devrim karşıtlı̆̆ı" ve "devlet düşmanlığı" suçundan idam edilenlerin sayısı ise yaklaşık 680.ooo kadardır. (Bkz. Hosking, 2011, 637-645) Bu insanlar Sovyet ceza kanununun 58. maddesi gereğince Troçkistler, casuslar, Sultan Galiyevciler vb. olarak suçlanmışlardır. ${ }^{3}$

Söz konusu süreç Sovyet edebiyatını da etkilemiştir. Pek çok yazar ve şair halk düşmanı olarak suçlanıp sürgüne gönderilmiş ya da ortadan kaybolmuştur. (Bkz. Berlin, 2014, s.397-400) Ginzburg (1906-1977) da söz konusu yazarlar arasındadır. Ginzburg 1937 ylında başlatılan temizlik hareketinde halk düşmanı, terörist suçlaması ile tutuklandığında Kazan'da komünist partiye üye bir çalışandır. Ayrıca farklı edebiyat ve tarih dergilerinde yazılar da yazan Kazan Üniversitesi’nin tarih öğretmenidir. on yıl ıslah ve çalışma kamplarında mahkûmiyet, beş yıl da haklardan mahrumiyet cezasına mahkûm edilen yazar, tutuklanmasından mahkûmiyet kararına kadar geçen üç yıllık süreci farklı hapishanelerde, kalan on beş yllını da Sudar, Kolıma, Elgen gibi kamplarda geçirir (1937-1955).

1928 Sovyet ceza kanununun 58. maddesi karșı devrimci olmak ve anti-Sovyet çalıșmalarda yer almakla itham edilenlerin politik suç kapsamı içinde cezalandırılmasında en çok başvurulan ve uygulanan madde olmuştur. 1937-38 yıllarında "Büyük Terör" zamanında insanlar anti-Sovyet etkinliklerinde bulunmamıș olsa bile bu maddeye binaen tutuklanmıştır. 
Ginzburg, hapishanelerde ve çalışma kamplarında geçirdiği on sekiz yıl boyunca yaşadıklarını yaklaşık bin sayfalı "Anafora Doğru” (Krutoi marşrut 1) ve "Anaforun İçinde” (Krutoi marşrut 2) romanlarında anlatır. 1980 yılında kitabın önsözünü kaleme alan Heinrich Böll iki ciltlik bu kitabın "otobiyografik roman" kategorisinde yer alabileceğini ancak "roman" kelimesinin yaratılmış malzemeyi ifade etmediğini sadece yapı için söz konusu olduğunu belirtir (Bkz. Ginzburg, 2000, s.11).

1959 yılında yazmaya hız verdiği romanının birinci bölümünü 1962 yllında Sovyet sınırları içinde yayınlatmak ister; ancak başvurduğu yayınevlerince sansürden dolayı geri çevrilir. Bunun üzerine romanın ilk bölümü samizdat olarak elden ele çoğaltılır. Halk büyük bir ilgi ile kitabı çoğaltır. Sansür ve samizdat konusunda uzman Leningrad'lı bir profesörün Ginzburg'a, kitabının "yalnız zamanımızdaki yayın rekorunu kırmakla kalmayıp, aynı zamanda 19. yüzyılda gizlice basılan yayınlar rekorunu da kırdığını" ( Ginzburg, 2000, s.478) söylediği bilinir. Diğer yandan da Ginzburg kitabını Sovyet yayınevlerinde yayımlatmaya çalışsa da 1966 yılında "Yunost" dergisi baş editörü Polevoy'un "Bu kitabı basacağımızı cidden beklemiyorsundur umarım?” sözlerinden sonra bütün umutları sona erer.

"Gerçeğin bütünü değil elbette yazdiğım; ama gerçekten başka bir şey de değil.” ( Ginzburg, 200o, s.477) diyerek yazdıklarının tamamen yaşanmış gerçekler olduğunu ifade ettiği birinci romanı "Anafora Doğru”, ilk olarak 1967 yılında İtalya'da ardından da dünyanın farklı ülkelerinde kitap olarak yayınlanır. Her iki romanının Rusya'da basılması ise ancak yazarın ölümünden on yl sonra, 1988 yllında gerçekleşir.

Yazar her iki kitabında da gerek sorgulanma gerekse mahkûmiyet yıllarında yaşanan gerçekler karşısında hissettiği şaşkınlık ve merak duygusunu dile getirir. Nitekim birinci kitabının sonunda şöyle der: "Bu yıllar içinde birçok çatışmalı duygu yaşadım, fakat bunlarn içinde başta geleni hayret ve meraktı. Bunlarn olması mümkün müydü? Bunlar gerçekten oluyor muydu? Belki de hayatta kalmama yardımcı olan bu hayret ve meraktır, yalnızca bir kurban değil, ayn zamanda bir gözlemciydim” ( Ginzburg, 2008, s.347).

\section{Bulgular}

Ginzburg 1937 yılında 11 Şubat günü Kazan'da yayınlanan “Kızıl Tatar” dergisinin yazı kurulu içinde gizli bir terörist örgüt üyesi olma suçu ile tutuklanır. Belirtildiği gibi, tutuklandığı günlerden çalışma kamplarına kadar yaşadığı olayları "Anafora Doğru” kitabında anlatır. Bu kitabında tüm Sovyetleri içine alan tutuklama olaylarını, sorgulama sürecinde yaşadığı hapishane günlerini, içinde bulunduğu korku ve tereddüdü tüm ayrıntısı ve gerçekliği ile dile getirir. Bu nedenle de "Bunlar, kişi kültü dönemlerini anbean yaşamış sıradan bir komünistin anlarıdır" (Ginzburg, 1996, s.347) diye bitirir. Söz konusu kitabında Ginzburg, tutuklanmadan hemen önce toplumda çoğunluğun hissettiği acaba ben de suçlanarak tutuklanır mıyım? sorusunu kendisine sorar ve hiçbir gerekçe bulamaz:

\footnotetext{
"Mantığım beni tutuklamaları için kesinlikle hiçbir neden olmadığını söylüyordu. Elbette gazetelerde yayımlanan halk düşmanlarına ilişkin suçlamalardaki saçmalığı ve gerçekdışılığı bazı şeylerin vahşice abartıldığını fark ediyordum kendi kendime hala, bu yazılanlarda gerçeğin bazı kırıntılarının olması gerektiğini düşünüyordum...peki ben nasıl suçlanmıştım, kafamda parti hattının doğruluğuna ilişkin en ufak bir şüphe bile yokken ve muhalefetle hiçbir zaman bir ilişkim olmamışken?”(Ginzburg, 1996, s.34).
} 
Bütün bu düşüncelerine rağmen 58.maddenin 8. ve 11.firkalarına göre4 tutuklanır ve sorgusunda terörist örgüt üyesi olduğunu itiraf etmesi için zorlanır. İtiraf belgesini imzalamak istemeyince de sürekli işkencelerin ve sorgulamaların yapıldığı ünlü “Siyah göl” binasına götürülür. Burası, mahkûm yaşamının ilk gerçeğidir.

\begin{abstract}
"İşte cehennemin kendisi...solumda, asma kilitli ve sürgülenmiş kapılar, kapılar, kapılar ...uzak taşra kasabalarındaki tüccarların, devrimden önce, depolarında kullandıkları antika türden, paslı devasa asma kilitler. Kapıların ardında ise, elbette benden önce bu cehenneme tıkılan komünistler, arkadaşlarım vardı....” ( Ginzburg, 1996, s.51).
\end{abstract}

Ginzburg "arı kovan gibi kayniyordu”, "hapishaneler tıklım tıklım doluydu” diyerek tutuklu sayısının fazlalığına dikkat çektiği hapishaneler ve işkencelerle dolu üç yılın sonunda ölüm cezasına çarptırılabileceğini düşünürken "hapishanelerde on yll azami tecrit, beş yll için medeni haklardan tecrit ve bütün kişisel mülkiyetinin müsaderesi" cezası alır. Bunun üzerine "On yıl! On yıl! Demek hayattayım!" (Ginzburg, 1996, s.149) diyerek verilen ceza karşısında şaşkınlığını ve sevincini dile getirir.

O günlerde kendisinin ve arkadaşlarının tek dileğini “Bu duvarlardan mümkün olduğu kadar uzak bir yere olsun da isterse bütün yol boyunca prangalar içinde olalm ve Sibirya'nın en karanlk yerlerine ya da başka yerlere gidelim, razıydık" (Ginzburg, 1996, s.121) sözleriyle dile getirir. Hatta doğuya giden trenin 7 numaralı vagonundaki yolculuğu başladığında "Kürek cezası! Ne büyük mutluluk!" (Ginzburg, 1996, s.134) diyerek Boris Pasternak'ın bir şiirindeki dizeleri hatırlar. Ginzburg'un mahkûmiyet ve kamp yaşamı bu aşamadan sonra başlar. Belirtildiği gibi, "Anoforun İçinde" adlı ikinci otobiyografik romanında, kamplarda geçirdiği on beş ylllı süreci oldukça detaylı bir biçimde aktarır.

Aylarca süren tren ve gemi yolculuğu, kilometrelerce yürüyüşler ve sonunda vardıkları Kolıma çalışma kampı mahkûmiyetinin sonuna kadar çalışacağı kamptır. Ginzburg'a göre Kolıma doğal bir ıslah ve çalışma kampıdır. Nitekim uzun gemi yolculuğundan sonra ulaştıkları Kolıma'da net bir ufuk çizgisi görme umuduyla etrafa baktı̆̆ını; ancak hapishane duvarlarını anımsatan morumsu tepelerle kuşatılmış olduğunu belirtir: "Her tarafi bana hapishane duvarlarını anımsatan morumsu tepelerle kuşatılmıştı. Burada kaldığım yıllar boyunca hiçbir zaman geniş bir ufuk göremedim” (Ginzburg, 1996, s.301).

Kolıma, en uzun süre kaldığı çalışma kampıdır. Bu kamp Rusya’nın kuzeydoğusundaki Pasifik kıyılarında yer alan maden kaynakları açısından zengin; ancak yaşanması en zor yerlerden biridir. Applebaum "Gulag” kitabında bir tarihçinin Kolıma kampını “ bir nehir, bir dă̆ sınırı, bir bölge ve bir metafor olarak tanımladığını belirtir (Applebaum, 2008, s.85).

Tüm zorlu yolculuk boyunca olduğu gibi Kolıma kampında da Sibirya ile özdeşleşen soğuklardan sıklıkla bahseder. Bu soğuk, mahkûmları güçsüz ve savunmasız bırakan, hareketlerini kısıtlayan, özgürlük duygularını engelleyen bir soğuktur. Her kamp için farklı olmakla birlikte kanunlara göre, Kolıma kampında termometrenin -50 dereceyi göstermesi çalışmamak için yeterlidir. Ancak Ginzburg çok soğuk kış günlerinde termometrenin -50 dereceyi göstermesine rağmen sorumlu nöbetçiyi ikna edemediklerini anlatır:

“ -49 derece, olabilecek en kötü dereceydi, çünkü termometre -50 dereceyi gösterdiği zaman insanların resmen tıbbi koruma altına alınmaları gerekiyordu. -50 derecenin anlamı, yönetimin o gün ormandaki çalışmayı tatil etmesiydi. Fakat görevli nöbetçinin derecenin -49'un altına düşmüş olduğunu kabul etmesini beklemek boşunaydı” (Ginzburg, 2000, s.56).

1 Aralık 1934 yasası: S. Kirov’un öldürüldüğü gün teröristlere karşı işlemek üzere son sürat geçirilen yasa; buna göre ölüm cezalarında temyiz hakkı olmayacaktı ve infaz 24 saat içinde yerine getirilecekti. 
Kamp yaşamının simgelerinden bir diğeri ise dikenli tellerdir. Ginzburg, Magadan'daki Kolıma kampına gidene kadar kaldığı geçici kampların dikenli tellerine vurgu yapar. Kitabın pek çok yerinde "Kamp birbirine girmiş yoğun bir dikenli tel barikatıyla korunuyordu.", "Dikenli tellerden oluşan çitlerin iç tarafinda kadınlar görüyorduk.” (Ginzburg, 1996, s.277) gibi cümleler yer alır.

Aylarca süren zorlu tren yolculuğunun ardından ilk geçici (transit) kamp Elgen kampı yakınındaki Sudar'dır. Sudar gibi pek çok kampın girişinde ve farklı bölümlerinde de sloganlar dikkat çeker. Örneğin "Fedakârca çalışmamız işçi ailesine yeniden katılmamızı sağlayacak." "Haydi bu karargâhtaki devlet çiftliğinin üretim planım gerçekleştirelim ve aşalım!” (Ginzburg,1996, s.44) gibi pek çok sloganları kamplarda görmek mümkündür.

Sudar ve diğer kamplardaki insanları çalışmaya ve umut etmeye götüren sloganlara rağmen kampların yaşam şartları çok kötüdür. Örneğin Ginzburg Sudar'daki kulübeleri şöyle betimler: "Sudar kulübelerinin yalnızca lafta kulübe olduğunu belirtmeliyim ... tavanında iki delik açılmış karla kapl,, buzdan yapılmış iki adet çökmüş barmaktan ibaretti. Eskiden uzunlamasına yayılmış bu delikleri eskimiş kalın paltolarla her gün yeniden tıkamaktı" (Ginzburg, 1996, s.39).

Mahkûmların kamp yaşamlarından geriye kalan en önemli kelimelerden biri "açlık" ve "ekmek”tir. Bu kelimeler Soljenitsın'ın, Şalamov'un, Salahov'un ve daha pek çok mahkûmun otobiyografik romanlarında tıpkı bir leitmotif gibi tekrarlanır. Örneğin Soljenitsın’ın “İvan Denisoviç’in Bir Günü” (Odin den’ İvana Denisoviça); Salahov'un "Kolıma Hikayeleri” (Kolımskie rasskazı) ve Şalamov'un "Kolıma Hikâyeleri” (Kolımskie rasskazı) eserlerinde bir lokma ekmeği yiyebilmek ya da sakladığı ekmeğin çalınmaması için verilen emek anlatılır. Ginzburg da eserinde kendisi ve diğer mahkûmlar için ekmeğin anlamını şöyle ifade eder:

"Açlık; her geçen gün ekmek tayınları biraz daha küçülüyor, biraz daha hayal kırıı bir hale geliyordu. Ĕger yarısını sabaha bırakırsanız bütün gece uyanık kalırdınız. O ekmek uyumanızı engeller ve saman yastıkta onu düşünüp durmaktan işkence çekerdiniz. Bu bir dinamitin üstünde yatmak gibi bir şeydi. Sabaha kadar bekleyebilmişseniz onu bir hamlede mideye indirirdiniz. Ama tamamını akşamdan yemişseniz, sabahki zor çalışmaya giderken açlı̆̆a nasıl dayanacaktınız?” (Ginzburg, 200o, s.64).

Ayrıca diğer mahkûmlarla birlikte ormanda çalışırken ekmek kırıntılarının kendileri için ne kadar özel ve önemli olduğunu da sık sık dile getirir: "Ekmek kırıntılarımızı iki parçaya bölüyorduk. Bir kısmın sabahlarl sıcak suyla yiyorduk, diğer kısmın da ormanda üstüne kar serperek” (Ginzburg, 2000, s.339).

Ölmek üzere olduğunu bilen mahkûmlar için de ekmek çok önemlidir. Nitekim ölmeden önce kendilerine verilecek son tayın haklarının bir arkadaşlarına verilmesi için istekte bulunurlar: "Bak hemşire...eğer akşam yemeğinden önce gidersem, tayınımı Sergey'e verin. Bizim koğuşta birçok çakal var. Onların ne hirsız olduklarını bilemezsin" ( Ginzburg, 2000, s.149 ). Dolayısıyla soğuğun ve açlığın, mahkûmların ıslah ve çalışma kamplarındaki mahkûmiyetlerinin ayrılmaz bir parçası olduğu görülür. Ginzburg da savaşın başladığı 1941 yılının kış aylarında, soğuk ve açlığın kendisinde yarattığı duyguyu "Soğuk ve açlık, açlık ve soğuk. Bu benim kamplardaki en karanlık, en ölümcül, en Allah'ın cezası kışım olmalıyd”" (Ginzburg, 2000, s.57) diyerek ifade eder.

Ginzburg, mahkûmiyet yıllarının bir kısmında hasta bakııı olarak çalışır. Orada yaşanan hastalıkları ve bunların sebep olduğu şartları gözlemleme imkânı bulur. Dolayısıyla mahkûmların maruz bırakıldığı fazla çalışma saatleri ve kötü yaşam şartlarından dolayı da mahkûmlarda genellikle aynı hastalıkların görüldüğünü belirtir: 
"Ne akciğer iltihaplanması, ne müzmin bronşit, ne soğuk algınlığı söz konusu değildi....Yalnızca çıbanlar ve beslenme yetersizliğinden doğan ülserler; yalnızca yer çekimi eksikliği dolayısıyla yürürken sallanma; yalnızca dişetlerinde ve elle çekilip çıkarılacak ölçüde zayıflamış dişlerde iltihaplanma” ( Ginzburg, 2000, s.61).

Yetersiz beslenmenin neden olduğu ve doku uyuşmazlığı olarak tanımlanan, vücudun farklı yerlerinde çıkabilen çıban ya da yaralar en sık rastlanılan hastalıktır. Ginzburg’un kampta sevdiği, kamp doktoru mahkûm Anton'un ayağında da böyle bir yara çıkar. Mahkûmiyet yıllarında yarası zaman zaman iyileşip kötüleşse de bu yara, özgür kaldıktan sonra 1959 yılında Anton’un ölümüne neden olur. Ölmeden iki gün önce Ginzburg’a yarasını göstererek, aslında bu yaraların Kolıma mahkûmları için bir damga olduğunu söyler: "Auschwitz ve Dachau kamplarında kalanlar bileklerindeki damgadan tanınırlar. Kolıma mahkûmları ise açlığın yol açtığı dövmeden, bu işaretten tanınırlar" (Ginzburg, 2000, s.288).

Kamp yaşamının bir parçası olan hastalıklar pek çok ölümü de beraberinde getirir. Ginzburg kamp dispanserinde çalıştı̆̆ yıllarda pek çok ölüme şahit olur. Ancak hastalık nedeni ile ölümlerden başka bilerek ve isteyerek ölümler yani intiharlar da görülür. Applebaum "Gulag” adlı kitabında bu konuda hiçbir istatistik olmadığını belirtir (Bkz. Applebaum, 2008, s.338) Artık yolun sonuna geldiğini düşünen, dayanma gücü kalmamış, umudunu kaybetmiş kişiler intihar ederler. Ginzburg'un tanıdığı Shura, Hans, Lipa ve diğerleri ayakta kalmalarını sağlayan umut düşüncesini kaybetmişlerdir. Kampa geliş yolculuğunda 7 numaralı vagonda birlikte yolculuk yaptıkları arkadaşı, eski dil uzmanı ve çevirmen Polina da bunlardan sadece biridir. Polina'nın ayaklarının dibinde de "Artık sona geldim.” yazısı vardır.

“...Kamp botları sallanıyordu. Botların donu, sıcağı görünce çözülmeye başlamıştı. Bunlardan sürekli kirli bir sıvı damlıyordu. Kafası korkunç şekilde kararmış, dili dışarı fırlamış, gözler aynı Gogol'ün eski anıtındaki gibi dışarı firlamıştı... İnce bir burun alnının üzerine düşmüş bir saç buklesi. Polina Melkinova" (Ginzburg, 2000, s.118).

Kamp yaşamında hayatta kalmaya çalışan Ginzburg da 1944 yllında, oğlunun ölüm haberini aldığında tüm umudunu kaybettiğini ve ölümü istediğini belirtir: "O haftalarda muhafiz gözetimi altında olmasaydım ... Çevrem, tayganın o çalkantıl, uğuldayan buz gibi ırmakları ve firtınalarıla sarılıydı. Onlar bu zavallının kederli anılarını söndürebilirdi. Ama bir an için bile yalnız bırakılmıyordum" ( Ginzburg, 2000, s.109).

Bu kampta madenler, çeşitli inşaatlar, ormancılık işletme sahaları, ceza hücreleri, koğuşlarla birlikte doğum evleri ve kreşler de bulunur. Kamp kreşlerindeki çocukların bir kısmı kampta doğarken bir kısmı da 1937 yllında verilen operasyon talimatına 5 rağmen kamp şartlarında yaşamaya mahkûm edilmiştir. Elgen kampında Ginzburg'a verilen ilk iş de kreşlerdeki çocuklara bakıcılık yapmaktır. Kreşe ilk gittiğinde dikkatini çeken en önemli özellik çocukların çoğunun konuşamamalarıdır. Bunu şöyle dile getirir: "Dört yaşında olanlar yalnızca anlamsız, bağlantısız birkaç sözcük söyleyebiliyorlardı. Anlamsız bağırtılar, mimikler ve vuruşlar başlıca anlaşma yollarıydı” ( Ginzburg, 2000, s.23). Ginzurg’un şaşkınlığı karşında diğer bakıcı Anya’nın sözleri ise kamp kreşlerindeki çocukları bekleyen belirsiz geleceği ifade eder: "Konuşmaları nasıl beklenebilir ki? Kim öğretecek onlara? Konuşan yok ki çevrelerinde. Bebekler grubunda bütün zamanların karyolalarında yatarak geçiriyorlar" ( Ginzburg, 2000, s.23).

\footnotetext{
5 Bu talimat, hamile kadınların ve bebek emziren kadınların tutuklanmasını yasakliyordu. Ancak uygulamada hem hamile kadınlar hem de emziren anneler sürekli olarak tutuklanıyordu. (Applebaum, 2008, s. 316) 
Ginzburg onlara konuşmayı öğretmeye çalışır. Resimler çizer ve onların ne olduğunu söyler. Bir gün yine böyle resimler çizer ancak çocukların verdikleri cevaplar yine kamp çocuklarına uygun cevaplardır. Ginzburg çocuklarla diyaloğunu şöyle anlatır:

"Bak" dedim Ananstas'a çizdiğim evi göstererek "Bu nedir?" "Kulübe” diye yanıtladı küçük çocuk, son derece net bir şekilde. Evin yanına bir de kedi çizdim. Fakat hiçbiri bunu fark etmedi. ..sonra evin çevresine her zaman köy evlerinin çevresinde bulunan çitlerden çizdim. Peki bu ne? "Kamp" diye bağırdı Vera, neşeyle ellerini çırparak..." (Ginzburg, 2000, s.25).

Ginzburg “uzak gezegen” olarak tanımladığı Kolıma’da serbest çocuklar kreşine bakıcı olarak göreve başladığında da bu çocukların tıpkı büyükler gibi güneş ışığı ve vitamin yetersizliğinden dolayı yeterli hareketi gösteremediklerini ve sık sı hastalandıklarını belirtir. Ancak onlar Elgen çocukları kadar şanssız değillerdir:

\begin{abstract}
“Güneş ışı̆̆ı ve vitamin yetersizliği, Kolıma'nın serbest çocuklarını bile etkilemişti. Yaşlarının gerektirdiği canlılığı gösteremiyor ve sık sık hastalanıyorlardı. Yine de bir evleri olduğundan, okula her gün anneleri ve babaları tarafından getirilip götürüldüklerinden, Elgen çocuklarının mahkûm çocukları gibi yüreğinizin yağını eritmiyorlardı” (Ginzburg, 2000, s.196).
\end{abstract}

Kamplarda yaşanan açlık, hastalıklar ve ölümlere, intiharlara rağmen insanları ayakta tutan yegâne duygu umuttur. Anafora yaklaştığı ilk günlerden itibaren kendisinin ve çevresindeki diğer insanların içindeki hayatta kalma duygusunu "O sonu gelmez umudun aldatıcı ışı̆̆ı olmasaydı ne yapardık?" (Ginzburg, 1996, s.90) diyerek ifade eder.

Nakledildiği hapishanelerden biri olan Krasin hapishanesinde de hapishane şartlarına göre insanların yaşama dair umutlandığını ya da umutlarını kaybetmeye başladıklarını dile getirir: " Temel bir kural öğrendim. Daha kirli hapishane, daha kötü yemek, daha kaba ve daha disiplinsiz gardiyanlar, yaşamını daha az tehlikede olduğunun belirtisidir. Daha temiz hapishane, daha çok yiyecek, daha kibar gardiyanlar ise ölüme daha yakın olduğunun göstergesidir (Ginzburg, 2000,s.93).

Ayrıca tüm mahkûmların, zorlu Elgen kampının çalışma ve yaşam şartları karşısında da umutlarını kaybetmemeye çalıştıklarını "Umut her zaman vard. Gaz odalarına ya da dar ağacma gönderilmiyorduk.... Rüzgardaki mum alevi gibi zayıf ve titrek olsa da umut içimizde her zaman göz kırpards.” (Ginzburg, 2000, s. 95) sözleri ile dile getirir. Hatta kendisinin, yaşama umudunu kaybettiği zamanlarda bile "Düşünüyorum, öyleyse varm" sözünü değiştirerek "Acı çekiyorum, öyleyse varım." (Ginzburg, 2000, s.109) sözüyle değiştirip kendi kendisine tekrarladığını belirtir.

\title{
Sonuç
}

Daha önce de belirtildiği gibi, söz konusu dönemde tutuklamalar ve ardından çalışma kamplarında yaşanan açlık, hastalık ve ölümlere şahit olan pek çok edebiyatçı bulunmaktadır. Solomon Volkov "Büyülü Koro" kitabında büyük terör zamanında tutuklanmış en az altı yüz yazarın bulunduğunu, bunun da Sovyet yazarlar birliği üyelerinin üçte birini oluşturduğunu belirtir (Volkov, 2010, s.134). Dolayısıyla gerek tutuklanarak hapse atılmış olsun gerek ortadan kaybolmuş olsun gerekse de çalışma kamplarında yıllarını geçirmek zorunda kalmış, farklı sanat dallarından pek çok sanatçı söz konusu süreçten bire bir ya da dolaylı olarak etkilenmişlerdir.

Bu çalışmada, yaşanan bu tarihi gerçeğin şahitlerinden biri olan Ginzburg'un kaleme aldığ "Anafora Doğru” ve "Anaforun İçinde” otobiyografik romanlarında Gulag çalışma kampları ile ilgili ne anlattığı ve nasıl anlattığı üzerinde durulmuştur. Kendisi gibi hapishane ve çalışma kamplarında yıllarını geçiren pek çok şair ve yazar gibi Ginzburg'un da yaşadıklarını, tarihi ve kişisel gerçeklikle bağdaşan bir şekilde 
kaleme aldığı görülür. "Okurun evine taşımak istediğim şey yalnızca acılarımın kronolojisi değil ruhun bu zahmetli yolculuğuydu.” (Ginzburg, 2000, s. 480) derken ortak hedeflerinin olduğunu düşündüğü insanlar tarafından milyonlarca kişiye yaşatılan acılar karşısında hissettiklerini ifade etmektedir. Islah ve çalışma kamplarında sıradanlığa ulaşmış açlık, hastalık ve ölümler karşısında yaşadığı şaşkınlık diğer yandan da ebeveynleri gibi mahkûm olan çocukların dramı, bu zahmetli yolculuğundan geri kalanlardır. Ayrıca romanın başında Ginzburg, yaşadığı olaylar karşısında mutlaka bir yanlışlık olduğunu düşünen ve komünist ideolojiye bağllığı devam eden bir kişidir; ancak ilerleyen zamanda bunun tam tersi yönde, Sovyet ideolojisine güvenmeyen bir kişiye dönüştüğü görülür.

Daha önce de belirtildiği gibi 1926 yllında genişletilerek uygulamaya koyulan ceza kanununun 58 . maddesi, kanıtlanmamış olsa da yalnızca casusluk şüphesi olan kişileri yıllarca hapishanelerde ve kamplarda mahkûm edilmesine neden olmuştur. Dolayısıyla bu madde ile terör suçunun kapsamı genişletilmiştir. Ancak Stalin sonrası dönemde gerçekleştirilen reformlar sayesinde, askeri ve olağanüstü hal mahkemeleri kaldırıldı ve yetkileri ciddi anlamda kısıtlandı. Ceza yasası; tutuklamalar ve göstermelik mahkemelerle ilintili olarak sık sık haksızlığa temel hazırladığı düşünülen; "karşı devrim hareketi," "terörist amaçlar," vs. gibi bazı belirsiz ve yoruma açık ifadelerden arındırıldı. Cezalarda belirgin indirimlere gidildi ve sanıkların sadece itiraflarından yola çılklarak mahkûm edilmeleri uygulamasina son verildi ( Hosking,2011: 735).

Kirov’un öldürülmesinin ardından özellikle, 1936-1938 yılları arasında yoğunlaşan ve büyük temizlik, büyük tasfiye ya da büyük terör olarak adlandırılan dönem için farklı yorumlar söz konusudur. Örneğin Soljenitsın bu dönemi, masumlara "ezici bir darbe" indirilen, "halkın yasasına cepheden bir saldır”" olarak nitelerken, aşırı ulusalcı tarihçi Oleg Platonov da 2004 tarihli, Devlete İhanet: Rusya’ya Karşı Komplo" adlı kitabında "1937 ve sonrasında eziyet gören insanlarm büyük kısmı Rus halkının düşmanlarıydr.” diye belirtir ( Volkov, 2010, s.134).

Günümüzde ise Sovyet kamplarında yaşanan acılar, haksızlıklar sadece yazarların ya da şairlerin belleklerinde kalan hatıralarla sınırlı değildir. Genç araştırmacılar olağanüstü çabalarla bu gerçekleri belgeler göstererek ortaya koymaktadırlar. Nitekim Hannah Arendt de "Totalitarizm’in Kaynaklar 3:Totalitarizm" adlı kitabında "Mevcut Rus yöneticilerin ikiyüzlülüğünden dolayı genç nesilden Rus entelektüeller şu anda isyan bayrağı açtılar. Zira insanların kitlesel olarak tasfiye, tehcir ve yok edildiklerinin bilinmesinin zamanı geldi" (Arendt, 2014, s.19) diyerek gerçeği su yüzüne çıkarmalarından duyduğu mutluluğu dile getirir.

\section{Kaynakça}

Applebaum, A. (2008). Gulag, (Çev: Ufuk Demirbaş) Ankara: Arkadaş

Arendt, H. (2014). Totalitarizm’in Kaynakları 3: Totalitarizm. (Çev:İsmail Serin) İstanbul: İletişim.

Berlin, İ. (2014). İstoriya svobodr. Rossiya, Moskva: Novoye literaturnoye obozronie.

Erenburg, İ. (1968). İ. Erenburg'un Hatıraları. İnsanlar Yıllar Hayatlar (Çev: Hasan Ali Ediz) Altın Kitaplar.

Ginzburg, E. (1996). Anafora Doğru (Çev: Gün Zileli) İstanbul: Pencere.

Ginzburg, E. (2000). Anaforun İçinde (Çev: Gün Zileli) İstanbul: Pencere.

Hosking, G. (2011). Rusya ve Ruslar. (Çev:Kezban Acar) İstanbul: İletişim.

İnanır, E. (2018). Rus Edebiyatında Bir Topos Olarak Sibirya, Tobider İnternational Journal of Social Sciences, 2(2), 64-73. 
Khairmukhanmedov, N. (2007). Stalin Dönemindeki Siyasi Muhalifleri Tasfiye Uygulamaları ve Çalıştırma Kampları. Bilig, 41,155-174

Riasanovski N.V., \& Steinberg M.D. (2011). Rusya Tarihi. (Çev:Figen Dereli) İstanbul: İnkılap.

Volkov S. (2010). Büyülü Koro. (Çev: Sabri Gürses) İstanbul: Yapı Kredi. 